\title{
Katarzyna Balbuza \\ (Poznań) \\ CONCORDIA, AETERNITAS IMPERII I KWESTIE \\ DYNASTYCZNE W MENNICZYM PROGRAMIE IDEOLOGICZNYM OKRESU PIERWSZYCH SEWERÓW
}

\begin{abstract}
The paper analyses all early Severan coinage commemorating the ideas of concord (concordia) in the state, in particular the concepts of marital concord (concordia felix), perpetual concord (perpetua concordia) and eternal concord (concordia aeterna), against the backdrop of the simultaneously propagated idea of aeternitas Imperii as well as the ideology and policy of succession of the ruling house.
\end{abstract}

\section{Key words}

Concordia, aeternitas, ideology, dynasty, Roman coinage 
Konkordia (concordia), rzymski odpowiednik greckiej homonoia ${ }^{1}$, odgrywała jedną $\mathrm{z}$ głównych ról $\mathrm{w}$ programie ideologicznym mennictwa ${ }^{2}$ okresu pierwszych przedstawicieli dynastii Sewerów³. Podobnie jak większość wcześniejszych włodarzy Rzymu dostrzegli oni potencjał tej należącej do najstarszych i najczęściej upamiętnianych w mennictwie rzymskim cnót $t^{4}$. Trzeba też zauważyć, że w sposób wyjątkowo umiejętny i pomysłowy wykorzystali ów potencjał w polityce i ideologii dynastycznej. Analiza monet wybijanych w imieniu Septymiusza Sewera i jego synów tudzież emisji zdobionych na awersie portretami kobiet $\mathrm{z}$ rodziny cesarskiej pozwala dostrzec nie tylko

\footnotetext{
${ }^{1} \mathrm{~W}$ tekście nie analizuję emisji prowincjonalnych z homonoia. Na temat homonoia ogólnie zob. H.A. Shapiro, Homonoia, LIMC V, 1, s. 476-479. Tu również podstawowa literatura przedmiotu. Homonoia w mennictwie: R. Pera, Homonoia sulle monete da Augusto agli Antonini, Genova 1984; O. Vacano, Typenkatalog der antiken Münzen Kleinasiens, red. D. Kienast, Berlin 1986; H.A. Shapiro, Homonoia, s. 477-479; P.R. Franke, Die Homonoia-Münzen Kleinasiens und der thrakischen Randgebiete, Saarbrücken 1997.

${ }^{2} \mathrm{~W}$ tekście stosuję następujące skróty nominałów: Au - aureus, D - denarius, Q - quinarius, $\mathrm{S}$ - sestertius, Dp - dupondius, As - assarius, $\mathrm{M}$ - medalion.

${ }^{3}$ Twierdzenie to bynajmniej nie oznacza, że w mennictwie późniejszych przedstawicieli dynastii, Heliogabala czy Sewera Aleksandra, nie propagowano idei zgody. Koncentruję się na monetach pierwszych Sewerów ze względu na wyraźne osadzenie zgody w klimacie wieczności, a przez to również w kontekście dynastycznym (na ten temat zob. też K. Balbuza, Aeternitas Augusti. Kształtowanie się i rozwój koncepcji wieczności w (auto)prezentacji cesarza rzymskiego (od Augusta do Sewera Aleksandra), Poznań 2014, s. 166-168, 174-178). W odniesieniu natomiast do promowania zgody na monetach okresu późnych Sewerów trzeba zauważyć, że cechą charakterystyczną tych emisji jest to, że awersy większości $\mathrm{z}$ monet zdobiły podobizny kobiet z rodziny cesarskiej (Julia Maesa, Julia Mamaea, Julia Cornelia Paula, Aquilia Severa, Annia Faustina, Orbiana), co ma znaczenie $\mathrm{w}$ kontekście rozpatrywanej tu polityki dynastycznej. Concordia Augustorum, zob.: Julia Maesa: RIC IV, 2, Elagab. 277* (D); Iulia Mamaea: RIC IV, 2, Sev Alex. 330 (D); Julia Cornelia Paula: RIC IV, 2, Elagab. 216 (D); Sallustia Barbia Orbiana: RIC IV, 2, Sev. Alex. 319-321, 655-658 (Au/D/Q/S/As). Wyjątek: RIC IV, 2, Sev. Alex. 551* (S). Concordia, zob. Julia Mamaea: RIC IV, 2, Sev Alex. 329, 367 (D); Julia Cornelia Paula: RIC IV, 2, Elagab. 380-385 (S/Dp/As); 386-387 (S/As - concordia aeterna); Aquilia Severa: RIC IV, 2, Elagab. 389-395 (S/Dp); Annia Faustina: RIC IV, 2, Elagab. 399 (S). Por. wyjątek: RIC IV, 2, Sev. Alex. 275 (D).

${ }^{4}$ Ogólnie o Konkordii z odesłaniami do źródeł i literatury przedmiotu, na temat typologii wraz z analizą ikonografii por. m.in.: T. Hölscher, Concordia, LIMC V, 1, s. 479-498 i V, 2, s. 333-340. O Konkordii w okresie wczesnego pryncypatu zob. m.in. J.A. Lobur, Consensus and Concordia and the Formation of Roman Imperial Ideology, New York 2008. Konkordia w mennictwie zob. J. Béranger, Remarques sur la Concordia dans la propagande monétaire impériale et la nature du principat, [w:] J. Béranger, F. Paschoud, P. Ducrey (red.), Principatus: études de notions et d'histoire politiques dans l'antiquité gréco-romaine, Genève 1973, s. 367-382; P. Zanzarri, La concordia romana: politica e ideologia nella monetazione dalla tarda repubblica ai Severi, Rome 1997; T. Mikocki, Zgodna, pobożna, płodna, skromna, piękna... Propaganda cnót żeńskich w sztuce rzymskiej, Wrocław 1997, s. 17-104; C. Noreña, Hadrian's Chastity, Phoenix 61, 2007, s. 296-317; idem, Imperial Ideals in the Roman West: Representation, Circulation, Power, Cambridge 2011, s. 132-135 ; A. Kluczek, Concordia ordinum, czyli o społecznych funkcjach pieniądza w Cesarstwie Rzymskim, [w:] XIV Ogólnopolska Sesja Numizmatyczna. Upieniężnienie. Kiedy moneta staje się pieniądzem, Nowa Sól 2011, s. 21-42.
} 
mnogość upamiętnień Konkordii, lecz także różnorodność, tak w zakresie brzmienia legend, jak i wzorów przedstawieniowych na rewersach. W zakresie doboru ikonografii i legend w tym czasie korzystano zarówno z wcześniejszych doświadczeń, jak i wprowadzano pewne innowacje, które zaważyły na oryginalności programu propagowania Konkordii. Idea zgody odegrała istotną rolę $\mathrm{w}$ promowaniu dynastii i kreacji jej pozytywnego $\mathrm{i}$ - jak z pewnością zakładano - oczekiwanego społecznie wizerunku.

W okresie republiki kult Konkordii należał do najbardziej popularnych i znaczących ${ }^{5}$, lecz pomimo tak długiej tradycji oddawania jej czci odniesienia do Zgody w mennictwie, tak wizualne, jak i werbalne, można zaobserwować dopiero w I w. przed Chr. ${ }^{6}$ Całopostaciowa ikonografia personifikacji zagościła na rewersach dopiero $\mathrm{w}$ okresie cesarstwa ${ }^{7}$, kiedy to określono podstawowe jej atrybuty: czarę ofiarną (patera) oraz róg obfitości (cornucopia). Kwestia ich selekcji oraz wzbogaceń podlegała jednak z czasem licznym modyfikacjom; wybór i układ wyróżników Konkordii na rewersach były najczęściej uzależnione od kontekstu (np. concordia, concordia orbis terrarum, concordia Augusti, concordia Augusta, concordia Augustorum, concordia Augustorum et Caesarum, concordia Imperii, concordia militum, concordia exercituum, concordia legionum, concordia equitum, concordia populi Romani, concordia praetorianorum, concordia provinciarum, concordia senatui, concordia felix, concordia aeterna). W związku z powyższym wyróżniki personifikacji zgody uległy z czasem zwielokrotnieniu i zróżnicowaniu (m.in.: gałązka, berło, kłosy zboża, podwójny róg obfitości, ołtarz, sztandar, kaduceusz (caduceus) etc.). Cnotę zgody symbolizowały też inne wzory

\footnotetext{
${ }^{5}$ Wzniesienie pierwszej świątyni poświęconej Konkordii ślubował w 367 r. przed Chr. dyktator Marek Furiusz Kamillus (M. Furius Camillus). Por. Ovid., Fasti 1, 637-644; Plut., Camill. 42. Por. E. Aust, Concordia, RE IV, 1901, col. 831-834.

${ }^{6}$ Zob. republikańskie denary Lucjusza Emiliusza Lepidusa Paulusa (L. Aemilius Lepidus Paullus) z ok. 62 r. przed Chr. (RRC 415/1, 417/1a-1b), Publiusza Fontejusza Kapitona (P. Fonteius Capito) z ok. 55 r. przed Chr. (RRC 429/2a-2b), Lucjusza Winicjusza (L. Vinicius) z ok. 52 r. przed Chr. (RRC 436/1) i Lucjusza Mussydiusza Longusa (L. Mussidius Longus) z ok. 42 r. przed Chr. (RRC 494/41-42c). Typologię monet republikańskich sporządził Tonio Hölscher (idem, Concordia, s. 480, 1-6). O propagandzie monetarnej w okresie republiki zob. L. Morawiecki, Pax et Concordia - polityczne i religijne aspekty personifikacji w republikańskim Rzymie, [w:] R. Sajkowski (red.), Religia i polityka w świecie antycznym, Ostróda 2005, s. 132-156.

${ }^{7}$ Najwcześniejsze jej przedstawienia w pozycji siedzącej (za Galby upowszechnia się ikonografia Konkordii stojącej, por. RIC I², Galba 35; 49; 54 (D)), stwierdzamy już na monetach wybijanych w imieniu Tyberiusza (por. np. RIC I², Tib. 55; 61; $67(\mathrm{~S})$ ). Inaczej podaje R. Peter, Concordia, LGRM I, s. 917, który najwcześniejszą w mennictwie ikonografię siedzącej Konkordii datuje na czasy Nerona. Typologię ikonografii Konkordii w mennictwie pryncypatu sporządził T. Hölscher, Concordia, s. 480-498 (Konkordia w pozycji siedzącej, stojącej, w grupie innych personifikacji, kobiety domu cesarskiego jako Konkordia, Konkordia jako atrybut etc.).
} 
przedstawieniowe (m.in. uściśnięte $\mathrm{dłonie}^{8}$, postaci cesarzy, współrządców, cesarzowych etc.).

Konkordia, niezależnie od okresu historycznego, zawsze symbolizowała konkretną wartość moralną, personifikując zgodę w kręgach społeczno-politycznych. W okresie republiki realizowała się ona w łonie ugrupowań politycznych, natomiast za cesarstwa uległa zindywidualizowaniu, odnosząc się do relacji międzyludzkich. Wyrażała harmonię i porozumienie w obrębie rodziny cesarskiej, uosabiała dobre stosunki między cesarskimi małżonkami lub rodzeństwem, czy parą niespokrewnionych ludzi - współrządców (concordia Augustorum), a także w ramach zgodnych relacji między innymi podmiotami społecznymi (armia, senat, grupy społeczne etc.).

Biorąc pod uwagę częstotliwość przywoływania zgody w mennictwie, zarówno $\mathrm{w}$ treści legend, jak i w ikonografii, pierwsi przedstawiciele dynastii Sewerów zajmowali silną pozycję w długim szeregu cesarzy deklarujących harmonię na najwyższych szczeblach władzy. Zgoda była upamiętniana na emitowanych $w$ ich imieniu monetach w kilku znanych już wcześniej odsłonach - w tej najbardziej ogólnej i uniwersalnej (concordia) ${ }^{9}$, w wyraźnym powiązaniu z osobą cesarza/cesarzy, którzy ją zapewniali i manifestowali (concordia Augustil concordia Augustorum) $^{10}$, oraz w odniesieniu do armii (concordia militum $)^{11}$. Warto jednak uwypuklić fakt, że kontynuacja tradycyjnych i sprawdzonych w mennictwie imperialnych wzorów nie oznaczała w tym przypadku braku oryginalności w kreowaniu nowych, które, notabene, trzeba interpretować przez pryzmat polityki i ideologii dynastycznej. Obok wymienionych wyżej i już wówczas znanych obrazów zgody wdrażano zupełnie nowe rozwiązania, które przyczyniły się nie tylko do pogłębienia jej znaczenia w odniesieniu do ideologii dynastii, lecz także do ideologicznego osadzenia dynastii panującej w kontekście gwiezdnej wieczności i nieprzemijalności. Wprowadzenie do zespołu brzmień legend namonetnych takich

\footnotetext{
${ }^{8}$ Wykaz świadectw numizmatycznych prezentujących ideę zgody za pomocą uściśniętych dłoni: T. Hölscher, Concordia, s. 491-492.

${ }^{9}$ RIC IV, 1, Sept. Sev. 313-314 (D); RIC IV, 1, Sept. Sev. (Julia Domna) 637 (D); RIC IV, 1, Carac. 212*, 318 (D); RIC IV, 1, Carac. (Plautilla) 360; 370; 372 (Au/D); RIC IV, 1, Geta 40; 85 (D). Legendy: CONCORDIA/CONCORDIAE.

${ }^{10}$ RIC IV, 1, Sept. Sev. ${ }^{*}$ s. 100; 255; 330A; 814 (Au/S); RIC IV, 1, Carac. 152; 459; 508 a-c; 518; 537 (Au/S/As); RIC IV, 1, Carac. (Plautilla) 359; 363 (a-b); 364; 580 (Au/D/Q/Dp/As); RIC IV, 1, Geta 73 (a-b); 86 (a-b); 134 (a-b); 164; 165; 184 (Au/D/S). Legendy: CONCORDIA AVGVSTORVM/CONCORDIA AVG/CONCORDIA AVGG/CONCORDIAE AVGG.

${ }^{11}$ RIC IV, 1, Sept. Sev. 108; 256; 502 a-b (Au/D); RIC IV, 1, Carac. 232-233 (D); RIC IV, 1, Geta 135; $141 \mathrm{a}-\mathrm{b}(\mathrm{S})$. Legendy: CONCORDIA MILIT/CONCORDIA MILIT S C/CONCORDIAE MILITVM.
} 
określeń zgody jak felix, perpetua czy aeterna pozwoliło zaaranżować nową jakość, obdarzyć tę wartość ożywczym duchem i pogłębionym sensem, zarówno w kategoriach ziemskiego, jak i pozaziemskiego świata. Ponadto propozycja zobrazowania wszystkich emisji z concordia aeterna za pomocą wizerunków członków dynastii, a większości tychże z atrybutami Aeternitas, niemal zupełne zatem odejście od przywoływania tradycyjnej personifikacji bóstwa, pozwoliła na osadzenie dynastii w otoczce trwania nieustannego i wiecznego ${ }^{12}$. Dzięki temu manewrowi można było kreować nie tylko pozytywny, ale i metafizyczny obraz dynastii, której reprezentanci ręczyli za wiecznotrwałość Rzymu.

Zacznijmy od upamiętnień zgody rozumianej w wymiarze tradycyjnym. W mennictwie Septymiusza Sewera i na monetach bitych w imieniu jego dwóch synów, Karakalli i Gety, podejmowano ideę zgody w zasadzie przez cały okres ich rządów. Rozpowszechnianie tej idei rozpoczęto emisjami w Laodycei w latach 196-202. To właśnie tam ukazały się monety posiadające na awersie portret Julii Domny, upamiętniające zgodę, która otrzymała swoje zwyczajowe atrybuty, tj. czarę ofiarną i podwójny róg obfitości ${ }^{13}$. Niemal w tym samym czasie, w roku 197 po Chr., emisję denarów z wyobrażeniem uniwersalnej zgody rozpoczęto również $\mathrm{w}$ mennicy rzymskiej ${ }^{14}$. W tych wczesnych latach wybijano tu też w imieniu cesarza monety upamiętniające ideę concordia Augustorum ${ }^{15}$, eksponując w ten sposób zgodę gwarantowaną przez rodzinę cesarską (na rewersie zobrazowano ją za pomocą postaci Karakalli i Gety, trzymających między sobą statuetkę Wiktorii), ideę concordia felix, wskazującą na zgodę małżeńską między Septymiuszem Sewerem i Julią Domną ${ }^{16}$, oraz ideę concordia militum, przy czym ostatnia $\mathrm{z}$ wymienionych była $\mathrm{w}$ tym czasie rozpowszechniana także przez mennicę wschodnią w Laodycei ${ }^{17}$. Koncepcję zgody $\mathrm{w}$ armii wyobrażano za pomocą personifikacji Konkordii trzymającej w ręku sztandary wojskowe. Znaczący w kontekście wzrostu liczby emisji i typów był rok 202 i lata kolejne, aż do roku 210. Wówczas to obok znanych już typów o niemal identycznej ikonografii podejmują-

${ }^{12}$ E. Manders, Coining Images of Power. Patterns in the Representation of Roman Emperors on Imperial Coinage, A.D. 193-284, Leiden 2012, s. 41, niesłusznie zaklasyfikowała do kategorii „Dynastic representations” wyłącznie typy monetarne CONCORDIA FELIX, CONCORDIA AVGG i CONCORDIA AVG. Natomiast emisje z CONCORDIA AETERNA przypisała tylko do kategorii monet reprezentujących tematykę Aeternitas (ibidem, s. 47). Por. też ibidem, s. 187-188, przyp. 3.

${ }^{13}$ RIC IV, 1, Sept. Sev. (Julia Domna) 637 (D).

${ }^{14}$ RIC IV, 1, Sept. Sev. 103 (D). Legenda: P M TR P V COS II.

${ }^{15}$ RIC IV, 1, Sept. Sev.*, s. $100(\mathrm{Au})$.

${ }^{16}$ RIC IV, 1, Sept. Sev. 547 (D). Legenda: CONCORDIA FELIX.

${ }^{17}$ RIC IV, 1, Sept. Sev. 108; 502 a-b (Au/D). 
cych temat zgody uniwersalnej (concordia) ${ }^{18}$, zgody gwarantowanej przez przedstawicieli dynastii rządzącej (concordia Augustorum) - Septymiusza Sewera i jego synów ${ }^{19}$ - oraz zgody panującej w szeregach armii rzymskiej $(\text { concordia militum })^{20}$, pojawily się oryginalne upamiętnienia nieustającej zgody (perpetua concordia) ${ }^{21}$ oraz zgody wiecznej (concordia aeterna) ${ }^{22}$.

Sposób upamiętniania uniwersalnej zgody, jaki obrano w przypadku mennictwa Septymiusza Sewera, znalazł kontynuację na monetach noszących wizerunki Gety (w latach 203-208 i 210-212 po Chr.) oraz Karakalli (w latach $210-217)^{23}$. Na szczególną uwagę w kontekście zagadnienia ideologii dynastycznej zasługuje ikonografia monet Gety zawierająca przedstawienie obu braci, Karakalli i Gety, podających sobie dłonie w geście zgody ${ }^{24}$. Ów wzorzec ikonograficzny był, być może, inspirowany mennictwem Septymiusza Sewera, który w sposób podobny upamiętniał ideę concordia Augustorum. Ikonografia rewersów przedstawiała synów cesarza stojących naprzeciwko siebie, podających sobie dłonie i trzymających posążek Wiktorii pomiędzy sobą (il. 1), bądź samego Septymiusza Sewera w towarzystwie Karakalli, zwróconych ku sobie, składających ofiarę na ołtarzu i wieńczonych przez Wiktorię ${ }^{25}$. Impuls w kwestii wyboru wzoru przedstawieniowego mogły dla Septymiusza Sewera stanowić wzory antonińskie, $\mathrm{z}$ tym że tam wchodziły $\mathrm{z}$ reguły $\mathrm{w}$ grę relacje między cesarskimi współmałżonkami. Rewersy monet antonińskich zdobiła albo personifikacja Konkordii z jej atrybutami ${ }^{26}$, albo para cesarska ukazana w pozie dextrarum iunctio, w towarzystwie personifikacji Zgody (il. 2) ${ }^{27}$.

${ }^{18}$ RIC IV, 1, Sept. Sev. 313-314 (D).

${ }^{19}$ RIC IV, 1, Sept. Sev. 255; 330A; $814(\mathrm{Au} / \mathrm{S})$.

${ }^{20}$ RIC IV, 1, Sept. Sev. $256(\mathrm{Au})$.

${ }^{21}$ RIC IV, 1, Sept. Sev. 312 (Au). Legenda: PERPETVA CONCORDIA

${ }^{22}$ RIC IV, 1, Sept. Sev. 522 (D). Legenda: CONCORDIAE AETERNAE.

${ }^{23}$ RIC IV, 1, Geta 40; 85 (D). RIC IV, 1, Carac. 212*; 318 (D); RIC IV, 1, Carac. (Plautilla) 360; 370; $372(\mathrm{Au} / \mathrm{D})$. Ikonografia: Konkordia siedząca lub stojąca trzyma czarę ofiarną i podwójny róg obfitości lub składa ofiarę na ołtarzu.

${ }^{24}$ RIC IV, 1, Geta. 40 (D).

${ }^{25}$ RIC IV, 1, Sept. Sev. 814 (S).

${ }^{26}$ Zob. RIC III, Ant. Pius (Faustina I) 328-330; 335-337; 1074-1076 (Au/D); RIC III, Marc. Aur. (Faustina II) 1625-1627. Legendy: CONCORDIA S C/CONCORDIA AVG/CONCORDIA AVG S C.

${ }^{27}$ Zob. RIC III, Ant. Pius 402 (a-b); 434; 441; 1253 (a-b) (Au/S). Legendy: VOTA PVBLICA/VOTA PVBLICA S C/CONCORDIA TR POT III COS II. O przedstawieniach typu dextrarum iunctio zob. A. Alexandridis, Die Frauen des römischen Kaiserhauses. Eine Untersuchung ihrer bildlichen Darstellung von Livia bis Iulia Domna, Mainz 2004, s. 95-98. O dextrarum iunctio w kontekście reliefu z łuku z Leptis Magna: C. Rowan, Divine Ideology and the Visualisation of Imperial Power in the Severan Period, Cambridge 2012, s. 91-93. Cesarzowe i Concordia: RIC III, Ant. Pius (Faustina I) 328-330; 335-337; 1074-1076 (Au/D/S); RIC III, Marc. Aur. (Faustina II) 1625-1627 (As). Para cesarska: RIC III, Ant. Pius 402 a-b; 434; 441; 1253 (Au/S). Szerzej na ten temat: C. Noreña, Hadrian's Chastity, s. 135. 
Idea concordia Augustorum pojawiła się również na monetach bitych dla synów Sewera. Momentem inaugurującym tego rodzaju deklaracje były lata kluczowe dla kwestii dynastycznych pierwszych Sewerów, tj. 202 i $203^{28}$, ale także lata kolejne, aż do ok. 214 r. ${ }^{29}$ Ikonografia niektórych monet sugerowała ton dynastyczny. W mennictwie emitowanym w imieniu Karakalli, starszego syna cesarza, obserwujemy zasadniczo wierność jednemu ze wzorów ikonograficznych z mennictwa Septymiusza, ukazującemu obu braci z posążkiem Wiktorii $^{30}$. Nieco jednak inny wzór przedstawieniowy otrzymały rewersy sesterców, przedstawiające Karakallę i Getę stojących naprzeciwko siebie, wieńczonych odpowiednio przez Apollona (najprawdopodobniej) i Herkule$\mathrm{sa}^{31}$, czy rewersy asów, na których Karakalla jest wieńczony przez Wiktorię, natomiast Geta przez Apollona ${ }^{32}$. Głównymi bohaterami rewersów monet bitych w imieniu Gety są także obaj bracia ukazani w geście dextrarum iunctio (niekiedy w stroju wojskowym i z włóczniami) lub składający ofiarę na ołtarzu, czasem w towarzystwie Pietas lub Konkordii, a innym razem wieńczonych przez Wiktorię lub Apollona, albo też oba te bóstwa.

Wreszcie, wzorem mennictwa ojca, na monetach emitowanych dla obu synów można dostrzec wagę idei concordia militum. Zgoda w legionach to niemal najważniejszy postulat państwa rzymskiego, który nigdy się nie przedawniał, aktualny w każdych okolicznościach, a już zwłaszcza w sytuacji braku stabilizacji wewnętrznej i zewnętrznej w państwie. Na zgodzie w armii i lojalności legionów oparte były bezpieczeństwo i trwałość państwa. W imieniu Septymiusza Sewera mennica rzymska wyemitowała w latach 197-202 (203) aureusy i denary, demonstrujące na rewersie uosobienie Konkordii stojącej w otoczeniu sztandarów wojskowych, niekiedy z berłem w ręce ${ }^{33}$ (il. 3-4).

Emitowane za Sewerów monety z concordia militum mogły sygnalizować istnienie problemów w armii rzymskiej czy zagrożenie dla życia cesarza ${ }^{34}$. W latach 203-208 do zgody w armii nawoływały monety emitowane w imieniu młodszego syna cesarza, Gety, który był wówczas w randze cezara ${ }^{35}$, na-

\footnotetext{
${ }^{28}$ RIC IV, 1, Carac. 459; RIC IV, 1, Carac. (Plautilla) 359; 363 a-b; 364; 580 (Au/D/Q/Dp/As); RIC IV, 1, Geta 134 a-b (S).

${ }^{29}$ RIC IV, 1, Carac. 152; 459; 508a-c; 518; 537 (Au/S/As); RIC IV, 1, Geta 73 a-b; 86 a-b; 134 a-b; $164 ; 165 ; 184(\mathrm{Au} / \mathrm{D} / \mathrm{S})$.

${ }^{30}$ RIC IV, 1, Carac. $152(\mathrm{Au})$.

${ }^{31}$ RIC IV, 1, Carac. 459; 508 a-c (S). Jeszcze inną ikonografię mają asy, gdzie ukazano męską postać w todze, w geście uściśnięcia dłoni z kobietą; RIC IV, 1, Carac. 518 (As; 210-213 r.).

${ }^{32}$ RIC IV, 1, Carac. 537 (As).

${ }^{33}$ RIC IV.1, Sept. Sev. 108; 256; 502 a-b (Au/D)

${ }^{34}$ H. Mattingly, E.A. Sydenham, RIC IV, 1, s. 68.

${ }^{35}$ RIC IV, 1, Geta 135; 141 (S/Dp/As).
} 
tomiast w 213 r. - Karakalli. W drugim przypadku lansowanie zgody w armii przypadło na czas po śmierci Septymiusza Sewera i po przejęciu przez Karakallę najwyższej władzy i być może było związane z działaniami, jakie cesarz prowadził w Germanii, lub z jego wyprawą na Wschód w 214 r. ${ }^{36}$

Zajmijmy się w tym miejscu zasygnalizowanymi na początku niniejszych rozważań, i oryginalnymi w skali całego mennictwa rzymskiego, szczęśliwymi, nieustającymi i wiecznymi obrazami zgody. W mennictwie Sewerów sensu podejmowania idei concordia felix, co zainaugurowały monety $\mathrm{z}$ wizerunkiem Julii Domny ${ }^{37}$, upatruje się w kontekście zgody małżeńskiej, która miała cechować związki Septymiusza Sewera i Julii Domny oraz Karakalli i Plaucylli ${ }^{38}$. Interpretację tę wspiera fakt, że emisje tego rodzaju były sygnowane podobiznami cesarzowych, Julii Domny i Plaucylli ${ }^{39}$. Również ikonografia, pozostająca $\mathrm{w}$ tonie swoich antonińskich pierwowzorów, wskazywała na kontekst małżeński; pary cesarskie zostały wyobrażone w stylu dextrarum iunctio $^{40}$. Identyczną ikonografię, $\mathrm{z}$ tym że zmienia się konfiguracja osób, miały aureusy i denary wybite w imieniu Karakalli z lat 201-206 (gdzie pomiędzy nim a Plaucyllą przedstawiono Konkordię; il. 5) ${ }^{41}$. Warto zauważyć, że określenie felix zostanie, poza okresem Sewerów, zastosowane ponownie zaledwie raz - na przełomie lat 307-308, w mennicy Lugdunum, na monetach Maksymiana i Konstantyna - oczywiście bez żadnych nawiązań do zgody małżeńskiej ${ }^{42}$.

Typ perpetua concordia występował na aureusach i pochodzi najprawdopodobniej z lat 202-210, z okresu rządów Septymiusza Sewera ${ }^{43}$. Awers został opatrzony legendą FELICITAS PVBLICA i ikonografią ukazującą popiersia pary cesarskiej skierowane ku sobie, natomiast rewers przedstawia zwrócone ku sobie portrety Karakalli i Gety w wieńcach laurowych. Zarówno chronologia wybicia aureusów, jak i ich legendy czy ikonografia wyraźnie wskazują na podłoże dynastyczne, a konkretnie - na następstwo tronu po Sewerze przez jego synów, Karakallę i Getę, i stanowią proklamację nieustannie trwa-

\footnotetext{
${ }^{36}$ RIC IV, 1, Carac. 232-233 (D).

${ }^{37}$ RIC IV, 1, Sept. Sev. (Julia Domna) 547 (D). Monety z portretami Julii Domny należą do drugiej emisji mennicy rzymskiej i pochodzą z lat 196-211.

${ }^{38}$ Por. RIC IV, 1, 77. Por. też R. Peter, Concordia, s. 918.

${ }^{39}$ RIC IV, 1, Carac. (Plautilla) 365 a-b (D).

${ }^{40}$ Por. K.K. Hersch, The Roman Wedding: Ritual and Meaning in Antiquity, Cambridge 2010, s. $190-211$.

${ }^{41}$ RIC IV, 1, Sept. Sev. 123-124 a-b (D).

${ }^{42}$ Concordia felix dominorum nostrorum: RIC VI, Maxim. 246-248 (Follis). Legenda: CONCORDIA FELIX DD NN.

${ }^{43}$ RIC IV, 1, Sept. Sev. 312 (Au). Legenda: PERPETVA CONCORDIA.
} 
jącej, niekończącej się zgody pomiędzy braćmi. Owe przedstawienia z członkami rodziny panującej ponownie przywoływały na myśl analogiczne wyobrażenia antonińskie ${ }^{44}$.

Typ concordia aeterna był natomiast rozpowszechniany na monetach wybijanych dla Septymiusza Sewera (Laodycea, 201-202?), jego starszego syna Karakalli (Rzym, 199-206, il. 6), żony tego ostatniego, Plaucylli (Rzym, data nieznana), a także Gety (198-200? $)^{45}$. W ramach tej samej dynastii monety z concordia aeterna ukazywały się później jedynie za rządów Heliogabala i były sygnowane imieniem jego pierwszej żony Julii Pauli ${ }^{46}$, a poza Sewerami concordia aeterna była upamiętniana tylko na monetach opatrzonych portretem Saloniny, żony Galiena ${ }^{47}$. Wzbogacenie idei zgody o semantykę wieczności, co obserwujemy na monetach wczesnoseweriańskich, jest ewenementem w skali mennictwa imperialnego.

Ikonografia grupy monet, obejmującej 12 typów, jest zróżnicowana. Na 75\% całego zespołu składają się egzemplarze z portretami Septymiusza Sewera i Julii Domny. Ich twarze, umieszczone obok siebie, patrzą w tym samym kierunku (w prawo). Portrety pary cesarskiej zdobią corona radialis ${ }^{48}$, która spoczywa na głowie cesarza, oraz lunula ${ }^{49}$, na której ulokowano popiersie cesarzowej. Wymieniony wzór przedstawieniowy znalazł się na monetach o najwyższych nominałach (aureus, denar), sygnowanych imionami wszystkich trzech reprezentantów najwyższej władzy - Septymiusza Sewera, Kara-

${ }^{44}$ C. Noreña, Hadrian's Chastity, s. 135.

${ }^{45}$ RIC IV, 1, Sept. Sev. 522 (D); RIC IV, 1, Carac. 36; 52; 59 a-c; 125 a-b (Au/D); RIC IV, 1, Carac. (Plautilla) 361 (Au/D); RIC IV, 1, Geta 7 a-b (Au). Legendy: CONCORDIAE AETERNAE.

${ }^{46} \mathrm{~W}$ mennictwie opatrzonym imieniem i podobizną Julii Pauli wspomniana cnota występuje na monetach wybitych w złocie (aureusy) i brązie (sesterce, asy), możliwe że w mennicach wschodnich; RIC IV, 2, Julia Paula 215; 386-387 (Au/S). Legendy: CONCORDIA AETERNA. Wzorzec ikonograficzny jest dla wszystkich nominałów wspólny - para cesarska, Heliogabal i Julia Paula, stoją naprzeciw siebie, podając sobie dłonie. Pomiędzy małżonkami stoi Konkordia. Monety wybite za Heliogabala miały zatem odnosić się do konkretnej kobiety z domu cesarskiego, identyfikując ją jako jego żonę i propagując wieczność dynastii (zob. L. De Arrizabalaga y Prado, The Emperor Elagabalus: Fact or Fiction, Cambridge 2010, s. 97).

${ }^{47}$ RIC V, 1, Salonina 34 (Ant.). Legenda: CONCORD AET.

${ }^{48} \mathrm{Na}$ temat corona radialis zob. M. Bergmann, Die Strahlen der Herrscher. Theomorphes Herrscherbild und politische Symbolik im Hellenismus und in der römischen Kaiserzeit, Mainz 1998; S. Berrens, Sonnenkult und Kaisertum von den Severern bis zu Constantin I (193-337 n. Chr.), Stuttgart 2004.

${ }^{49} \mathrm{O}$ symbolice półksiężyca jako atrybutu cesarzowych rzymskich zob. C. Salz, Die Mondsichel der Kaiserin, [w:] L. De Blois, P. Funke, J. Hahn (red.), The Impact of Imperial Rome on Religions, Ritual and Religious Life in the Roman Empire. Proceedings of the Fifth Workshop of the International Network Impact of Empire (Roman Empire, 200 B.C.-A.D. 476), Münster, June 30-July 4, 2004, Leiden-Bristol 2006, s. 232-238. 
kalli, Gety, a także Plaucylli w latach wspólnych rządów ${ }^{50}$. Pozostałe wzory rewersów, także w większości charakterystyczne dla najwyższych nominałów, stanowiące $25 \%$ z ogólnej liczby monet, ukazują członków rodziny cesarskiej w akcie dextrarum iunctio (różne konfiguracje: Karakalla i Plaucylla - il. $7^{51}$, Karakalla i Geta ${ }^{52}$ ).

Ideologię dynastyczną prezentowaną w aurze wieczności szczególnie intensywnie głoszono na aureusach i denarach bitych dla Karakalli, które bądź to manifestowały wieczną zgodę pomiędzy parą cesarskich rodziców ukazanych z symbolami astralnymi słońca i księżyca (w okresie od ok. 199 r. do ok. 206), bądź ukazywały emitenta w akcie dextrarum iunctio z bratem Getą lub z żoną Plaucyllą (202 r.). Dla zgody wiecznej pomiędzy członkami dynastii znalazło się też miejsce na aureusach i denarach sygnowanych imieniem Plaucylli, żony Karakalli, w ramach pierwszej emisji53. Gwarantami zgody wiecznej, rozumianej w sensie małżeńskim, jest tu para cesarska ukazana, podobnie jak na monetach Karakalli, w geście dextrarum iunctio. Uzupełnieniem tej ideologii było głoszenie concordia felix i obrazowanie jej za pomocą tej samej ikonografiii ${ }^{54}$. Ponadto trzeba dodać, że mennictwo opatrzone imieniem Plaucylli, upamiętniające pozostałe obrazy zgody, charakteryzowało się podobnym jak w przypadku męskich reprezentantów dynastii walorem różnorodności, a upamiętnianie owych rozmaitych odsłon idei przybrało tutaj charakter zdecydowany i regularny i - co warto uwypuklić - wyraźnie akcentowało aspekt dynastyczny. Monety wybijano w ramach emisji rzymskich i laodycejskich oraz $\mathrm{w}$ imieniu senatu (emisje stołeczne uwydatniały, obok zgody wiecznej, znaczenie zgody w sensie uniwersalnym, zgody cesarskiej lub zgody małżeńskiej ${ }^{55}$ (il. 8), natomiast egzemplarze z Laodycei reprezentowały skromniejszy repertuar, upamiętniając jedynie zgodę w znaczeniu uniwersalnym $^{56}$ ). Bazowy wzorzec ikonograficzny tych emisji stanowiło przedstawienie Konkordii trzymającej czarę ofiarną i berło lub czarę ofiarną i podwójne cornucopiae. Trzeba jednak pamiętać, że $\mathrm{w}$ odróżnieniu od górnolotnych idei

\footnotetext{
${ }^{50}$ RIC IV, 1, Sept. Sev. 522 (D); RIC IV, 1, Carac. 36; 52; 59 a-c; 125 a-b (Au/D); RIC IV, 1, Geta $7 \mathrm{a}-\mathrm{b}(\mathrm{Au})$; RIC IV, 1, Carac. (Plautilla) 361 (Au/D). Legendy: CONCORDIAE AETERNAE.

${ }^{51}$ RIC IV, 1, Carac. 60 (Au); (Plautilla) $361(\mathrm{Au} / \mathrm{D})$.

${ }^{52}$ RIC IV, 1, Carac. $61(\mathrm{Au})$.

${ }^{53}$ RIC IV, 1, Carac. (Plautilla) 361 (Au/D).

${ }^{54}$ RIC IV, 1, Carac. (Plautilla) 365 a-b (Au/D). Por. też monety Karakalli RIC IV, 1, Carac. 123-124 a-b (D). Legenda: CONCORDIA FELIX.

${ }^{55}$ RIC IV, 1, Carac. (Plautilla) 359-361; 363-365; 580 (Au/D/Dp/As). Legenda: CONCORDIAE, CONCORDIA AVGG/CONCORDIA AVGG S C, CONCORDIAE AETERNAE, CONCORDIA FELIX.

${ }^{56}$ RIC IV, 1, Carac. (Plautilla) 370; 372 (D). Legenda: CONCORDIAE.
} 
głoszonych na monetach zarówno relacja małżeńska Karakalli i Plaucylli57, jak i braterska między Karakallą i Getą ${ }^{58}$ dalekie były od zgodności. Co interesujące, na monetach Gety z lat ok. 200-202 proklamujących concordia aeterna nie ma deklaracji zgody $\mathrm{z}$ bratem ${ }^{59}$, natomiast odnajdujemy na nich zgodę wieczną, personifikowaną za pomocą portretów rodziców, Septymiusza Sewera i Julii Domny, ukazanych w dobrze znanej konfiguracji i z symbolami astralnymi.

Statystyka pokazuje, że najbardziej rozpowszechnionym wzorem przedstawieniowym monet pierwszych Sewerów, towarzyszącym legendzie concordiae aeternae, były portrety pary cesarskiej ukazane $\mathrm{z}$ wyróżnikami astralnymi słońca i księżyca. Nie można wykluczyć, że ten typ ikonograficzny wskazuje na kontekst szerszy aniżeli ten ograniczający się do proklamowania tradycyjnej zgody małżeńskiej czy pomiędzy członkami dynastii, zwłaszcza jeśli weźmiemy pod uwagę brzmienie legendy. Jak można domniemywać, lunula oraz corona radialis prezentowały cesarza jako ucieleśnienie Heliosa/Apollona, cesarzową natomiast jako Selene/Artemidę ${ }^{60}$. Słońce i księżyc to najbardziej charakterystyczne atrybuty Aeternitas, począwszy od czasów flawijskich, kiedy personifikacja Wieczności zagościła w mennictwie rzymskim po raz pierwszy (il. 9) ${ }^{61}$, a następnie była w nim obecna aż do pierwszej poło-

${ }^{57}$ Córka Plaucjana (C. Fulvius Plautianus), prefekta gwardii pretoriańskiej (praefectus pretorio), została poślubiona Karakalli w kwietniu 202 r., jednak małżeństwo szybko się rozpadło. Plaucylla została wygnana na Wyspy Liparyjskie lub na Sycylię (wedle Herodiana). Po śmierci Septymiusza Sewera, w lutym 211 r., została zamordowana z rozkazu Karakalli i skazana na potępienie pamięci (damnatio memoriae). Zob. Cass. Dio 77, 6, 3. Por. Hdn. 3, 13, 2-3; 4, 6, 3. O niezgodnym małżeństwie Karakalli i Plaucylli i ich złych relacjach wzajemnych por. Hdn. 3, 10; 3, 13; SHA, Sev. 14, 8 .

${ }^{58}$ Stosunki między Karakallą i Getą: Hdn. 3, 10; 4, 1; 3-4; Zosim. 1, 9. Geta został zamordowany rzekomo z powodu spiskowania przeciwko Karakalli (Cass. Dio 78, 2, 1-3), w dniu 26 grudnia 211 r. (zob. Cass. Dio 78, 2; Hdn. 4, 4-6; Aurel. Vict., Caes. 20, 32; SHA, Sev. 20-21; Carac. 2, 4; 10-11; Geta 2-3; 6-7; Zosim. 1, 9-10; Eutrop. 8, 19), zaraz po śmierci Septymiusza Sewera, która miała miejsce w dniu 4 lutego 211 r. (Cass. Dio 77, 17; SHA, Sev. 19, 1) i rozpoczęciu wspólnych rządów (por. Hdn. 3, 15; SHA, Sev. 20, 1; 23, 6; SHA, Carac. 2, 7; SHA, Geta 6, 1; Zosim. 1, 9; Eutrop. 8, 19). Getę skazano na damnatio memoriae (SHA, Carac. 1, 1; Eutr. 8, 19. Por. E.R. Varner, From Caligula to Constantine: Tyranny and Transformation in Roman Portraiture, Atlanta 2000, s. 19, cat. 45-46; idem, Mutilation and Transformation. Damnatio Memoriae and Roman Imperial Portraiture, Leiden 2004, s. 168-184; I. Mennen, The Image of an Emperor in Trouble. Legitimation and Representation of Power by Caracalla, [w:] L. de Blois, P. Funke, J. Hahn (red.), The Impact of Imperial Rome, s. 253-267, zwłaszcza. s. 260, przyp. 23.

${ }^{59}$ Zgoda pomiędzy braćmi była uwieczniana na monetach $\mathrm{z}$ legendą CONCORDIA/ CONCORDIA AVGG i CONCORDIA AVGVSTORVM (RIC IV, 1, Geta 40; 85?); 86 a-b; 134 a-b; 73 a-b; 164-165; $184(\mathrm{Au} / \mathrm{D} / \mathrm{S})$.

${ }^{60}$ A. Alexandridis, Die Frauen des römischen Kaiserhauses von Livia bis Iulia Domna in statuarischer, epigraphischer und numismatischer Überlieferung, Heidelberg 1996, s. 216.

${ }^{61}$ RIC II, 1, Vesp. 838-839; 856-867 (Au); RIC II, 1, Dom. 366; 375-376; 411 (Dp/As). 
wy II w. po Chr. (rządy Hadriana) ${ }^{62}$. Biorąc pod uwagę te symboliczne skojarzenia, można założyć, że mógł istnieć związek ideologiczny pomiędzy ideą concordia aeterna a koncepcją wieczności dynastii, a więc również poszczególnych jej członków ${ }^{63}$.

Potwierdzeniem tej interpretacji byłaby nie tylko występująca $\mathrm{w}$ omówionych wyżej emisjach typowa dla personifikacji Wieczności symbolika przedstawień ikonograficznych słońca i księżyca, którym towarzyszą wizerunki pary cesarskiej, lecz także podobna ikonografia rewersów monet, na których upamiętniano w tym czasie ideę wieczności (aeternitas Imperii). W ten sposób oba nurty ideologiczne personifikacji Zgody mogły współistnieć i przenikać się - wewnętrzny (prywatny/rodzinny) oraz zewnętrzny (oficjalny) ${ }^{64}$. Wspomnianą przed chwilą ideę aeternitas Imperii upamiętniano powszechnie na monetach bitych dla pierwszych przedstawicieli dynastii Sewerów. Hasło wieczności władzy cesarskiej uzupełniały wzory przedstawieniowe, których treścią były wizerunki reprezentantów najwyższej władzy Karakalli i Gety (il. 10) ${ }^{65}$ lub Septymiusza Sewera i Karakalli ${ }^{66}$. Na szerzenie się w tym czasie idei aeternitas wskazują nie tylko przytoczone dotychczas upamiętnienia numizmatyczne aeternitas Imperii i concordia aeterna, lecz również dowody na obdarzanie innych bóstw epitetem aeternus. Romy (Roma aeterna), Wiktorii (Victoria aeterna), Pokoju (Pax aeterna) ${ }^{67}$ czy Sola (Sol aeternus) ${ }^{68}$. Trzeba jednakże zgodzić się z Hansem Instinskym, że koncept dynastycznej

\footnotetext{
${ }^{62}$ RIC II, Trajan 91-92; 229; 241-242 (D); Hadrian 38; 48; 81; 114-115; 597 a-d; 744 (D/S/Dp).

${ }^{63}$ Podobnie S. Berrens, Sonnenkult, s. 42; s. 176-178, 186-189.

${ }^{64}$ Oba te nurty w programie ideologicznym Konkordii wyodrębnił T. Mikocki, Zgodna, s. 19-20.

${ }^{65}$ RIC IV, 1, Sept. Sev. 155 a-c; 174; 178A a-b; 251-252; (Julia Domna) 540-541 (Au/D). Legenda: AETERNIT IMPERI.

${ }^{66}$ RIC IV, 1, Sept. Sev. 250; (Julia Domna) 539 a-b (Au/D). Legenda: AETERNIT IMPERI; Gnecchi II, Giulia Domna 1, s. 77 (M); RIC IV, 1, Carac. 32; 122 (D); RIC IV, 1, Geta 5 (D).

${ }^{67}$ Roma Aeterna: RIC IV, 1, Sept. Sev. 291-292; 350G; 414; 613 (Julia Domna); 671; 691; 697 $(\mathrm{Au} / \mathrm{D} / \mathrm{S} / \mathrm{Dp})$; RIC IV, 1, Carac. 143-143A (Au/D); RIC IV, 1, Geta 19; 54 (D). Legenda: ROMA AETERNA/ROMAE AETERNAE.

Victoria Aeterna: RIC IV, 1, Sept. Sev. 94-95; 141; 170 (D); RIC IV, 1, Carac. 23; 47 a-b; $48 ; 317$ c (D/As); RIC IV, 1, Geta 23; 55; 101 (D). Legendy: VICT AETERN/VICT AETERNAE.

Pax Aeterna: RIC IV, 1, Sept. Sev. (Julia Domna) 118; 118A; 283; 601 (M); 745 (D/S); RIC IV, 1, Carac. $138(\mathrm{Au})$. Legendy: PAX AETERNA/PACI AETERNAE/PACI VAETERNAE/PACI AET. O uwiecznianiu cnót zob. K. Balbuza, Aeternitas Augusti, s. 183-189.

${ }^{68}$ CIL II, 259 - inskrypcja z ołtarza ku czci bóstwa lokalnego Sol Aeternus (S. Berrens, Sonnenkult, s. 43, przyp. 36) i Luna z Olisipo, ob. Lizbona (o dedykancie, namiestniku Luzytanii w okresie 198 a 209 po Chr., Decymusie Juniuszu (?) Coelianusie (D. Iun[ius] (?) Coelianus) zob. G. Alföldy, Fasti Hispanienses. Senatorische Reichsbeamte und Offiziere in den spanischen Provinzen des Römischen Reiches von Augustus bis Diokletian, Wiesbaden 1969, s. 147).
} 
aeternitas ma w przypadku pierwszych Sewerów bardziej znaczenie polityczne aniżeli religijne ${ }^{69}$.

Jak już zauważono wyżej, na związek między ideami wieczności władzy i wiecznej zgody w łonie rodziny cesarskiej wskazuje m.in. ikonografia monet $\mathrm{z}$ aeternitas Imperii oraz niektórych egzemplarzy z concordia aeterna, przedstawiająca członków dynastii rządzącej bądź to $\mathrm{z}$ typowymi atrybutami Wieczności, bądź sytuująca ich w sferze wieczności poprzez legendy. Obecny w obu typach emisji temat wieczności miał być warunkowany wiecznością wszystkich przedstawicieli dynastii - ich aeternitas realizowała się poprzez aeternitas państwa lub władzy cesarskiej i odwrotnie. Owe wzory przedstawieniowe nie były spotykane $\mathrm{w}$ dotychczas prezentowanych formach upamiętniania tych wartości ${ }^{70}$.

Obecność nowych określników zgody - felix, perpetua i aeterna - dowodzi nie tylko oryginalności i niesztampowości sewerowego programu ideologicznego w mennictwie, ale również wskazuje explicite na jego wymiar dynastyczny. Wyróżniki te podkreślały stałość, ponadczasowość zgody, jej niekończące się trwanie na ziemi, pojmowane $\mathrm{w}$ wymiarze ziemskim - perpetua concordia, czy spotęgowane, bo religijne trwanie wieczne (concordia aeterna). Taka zgoda, zwłaszcza w odniesieniu do przedstawicieli władzy najwyższej, miała mieć, wedle sposobu i form jej utrwalania, charakter niezmiennie trwały, dzięki czemu gwarantowała stabilność państwa i funkcjonującego w nim systemu politycznego. Właśnie ów zabieg, mający na celu wzmocnienie rangi i wymiaru zgody w wymiarze ogólnopaństwowym, zapewnianej przez pierwszych Sewerów, świadczy o wartości treści ideologicznych zawartych w przekazie monetarnym.

Prezentując w mennictwie Septymiusza Sewera wieczność dynastii w duchu wiecznej zgody między jej członkami, wywołano interesujące skojarzenie z twórcami schyłku republiki i początku pryncypatu, Cyceronem i Liwiuszem. Pierwszy z wymienionych - prekursor terminu aeternitas w literaturze łacińskiej - wyrażając swoją troskę o aeternitas Rzymu, zalecał, by porzucić waśnie, być obojętnym na ludzkie namiętności, temperować ludzi niespokoj-

${ }^{69}$ Por. H.U. Instinsky, Kaiser und Ewigkeit, Hermes 77, 1942, s. 340-341.

${ }^{70}$ Idei aeternitas Imperii nie prezentowano jak dotąd w mennictwie, natomiast sposoby i formy wizualnego upamiętniania aeternitas Augusti czy samej aeternitas nie nawiązywały za pomocą ikonografii do osób gwarantujących te wartości władców (szerzej na ten temat K. Balbuza, Personifikacja Aeternitas na monetach rzymskich propagujących idę̨ wieczności cesarza, StEurGn 8, 2013, s. 7-27 oraz eadem, Aeternitas Augusti, passim). Concordia natomiast, zarówno w swej uniwersalnej odsłonie, jak i concordia Augustil Augustorum, concordia militum były w tym czasie ilustrowane zgodnie $\mathrm{z}$ tradycyjnymi wzorami przedstawieniowymi. 
nych, nie dopuszczać do zamieszek wewnętrznych. Przekonywał Rzymian, że aeternitas Rzymu i państwa zależy od postawy samych obywateli rzymskich ${ }^{71}$. Również Liwiusz przestrzegał, że waśnie w społeczeństwie to najpoważniejsze zagrożenia dla aeternitas Rzymu. Był zdania, że wieczność miasta i państwa może budować tylko harmonia i zgoda wewnątrzpaństwowa a cnota obywatelska - concordia - której istnienie zależy od woli samych ludzi, jest gwarancją szczęścia, niezwyciężoności i - co szczególnie istotne - wieczności Rzymu $^{72}$. Obaj twórcy, Cyceron, i Liwiusz, przestrzegali swoich współrodaków przed zagrożeniami, jakie niosły ze sobą wojny.

W świetle niniejszych rozważań konieczne jest zwrócenie uwagi na kontekst polityczny wszystkich omawianych emisji, które ujrzały światło dzienne $\mathrm{w}$ początkach rządów Sewerów. Wiele $\mathrm{z}$ tych monet ukazało się w momencie strategicznym dla pierwszych reprezentantów dynastii, w kontekście wydarzeń związanych zarówno z polityką zewnętrzną (zwycięstwo Septymiusza Sewera $\mathrm{w}$ obu wojnach partyjskich, celebracja sukcesu odniesionego nad Partami ${ }^{73}$ ), jak i wewnętrzną (zakończenie wojen domowych skierowanych przeciw kontrkandydatom do cesarskiej purpury - Dydiuszowi Julianowi, Pescenniuszowi Nigrowi i Klodiuszowi Albinusowi ${ }^{74}$ ). W odniesieniu do ostatniego $\mathrm{z}$ aspektów polityki lata te miały też ogromne znaczenie dla ugruntowania pozycji nowej dynastii. W $196 \mathrm{r}$. ogłoszono bowiem decyzję o podniesieniu starszego syna Septymiusza Sewera do rangi cezara ${ }^{75}$, a 28 stycznia 198 r.

\footnotetext{
${ }^{71}$ Cic., Rab. Perd. 12, 33: „si immortal[lem] hanc civitate[m esse] voltis, si aeter[num hoc] imperium, si [gloriam] sempiternam [manere], nobis a nostris [cupi]ditatibus,a tu[rbulen]tis hominibus [atque no]varum rerum [cupidis, ab intestinis malis], a domesticis co[nsiliis] est cavendum”. („Chcecie aby to miasto nieśmiertelne było, aby to państwo końca nie miało, aby nasza sława wiecznie trwała, strzec się nam trzeba naszych namiętności, ludzi niespokojnych, chciwych odmian, wewnętrznych zaburzeń i domowych knowań (...)” - przekł. E. Rykaczewski).

${ }^{72}$ Liv. 2.44: „id unum uenenum, eam labem ciuitatibus opulentis repertam ut magna imperia mortalia essent” („To jest jedyna trucizna, to ta choroba państw bogatych, przez którą zginąć mogą i wielkie państwa (...)” - przekł. A. Kościółek); Liv. 5.7: „beatam urbem Romanam et inuictam et aeternam illa concordia” („Szczęśliwe miasto Rzym - wołali - niezwyciężone i wieczne przez tę zgodę!” - przekł. A. Kościółek). O concordia u Liwiusza: P.G. Walsh, Livy: His Historical Aims and Metods, Oxford 1961, s. 69-70.

${ }^{73} \mathrm{O}$ formach uczczenia zwycięstwa nad Partami wraz z odesłaniem do źródeł zob. K. Balbuza, Triumfator. Triumf i ideologia zwycięstwa w starożytnym Rzymie epoki cesarstwa, Poznań 2005, s. 129-137; ostatnio na ten temat K. Królczyk, Propagatio Imperii. Cesarstwo Rzymskie a świat zewnętrzny w okresie rządów Septymiusza Sewera (193-211 r.), Poznań 2014, s. 81-95.

${ }^{74}$ Wojny Septymiusza Sewera o władzę trwały w latach 193-197/198. Szerzej na ten temat, wraz z przywołaniem źródeł oraz zestawieniem opracowań naukowych, D. Janiszewska, Wojna domowa w Rzymie w latach 193-197, Poznań 2010; K. Królczyk, Propagatio imperii.

${ }^{75}$ SHA, Sev. 10, 3; 16, 3.
} 
do pozycji augusta (augustus) ${ }^{76}$. Także młodszy syn cesarza, P. Septymiusz Geta, awansował w tym samym czasie na cezara, tj. młodszego współrządcę ${ }^{77}$. W ten sposób synowie cesarscy zaczęli ucieleśniać gwarancje ciągłości dynastycznej w ramach nowej dynastii. Sam Septymiusz Sewer jeszcze w 195 r. przeprowadził retroaktywnie adopcję swojej osoby, a także członków dynastii, do rodu Antoninów (gens Antoniniana) ${ }^{78}$, ustanawiając pozorny związek z poprzednim domem panującym, a tym samym złotym wiekiem Antoninów. Wymienione wyżej manewry założyciela dynastii, odzwierciedlające jego ambicje dynastyczne, znajdowały odbicie w ówczesnym mennictwie, także tym akcentującym ideę zgody. Emisje te, współwystępujące z innymi istotnymi wydarzeniami $\mathrm{w}$ łonie polityki wewnętrznej państwa, jak m.in. adventus Septymiusza Sewera ${ }^{79}$, decennalia ${ }^{80}$, w tym zaślubiny Karakalli z Plaucyllą (9-15 kwietnia 202 r. $)^{81}$, mogły wyrażać ideę dynastyczną, którą niosły ze sobą powyższe zdarzenia. Kumulacja różnych uroczystości, wraz z zabiegiem promującym wieczną zgodę w łonie dynastii panującej, przyczyniała się do ugruntowania władzy i wykreowania korzystnego wizerunku dynastii. Ewidentnie dynastyczny kontekst emisji upamiętniających ideę zgody, mających za zadanie przygotować grunt ideologiczny pod wypromowanie nowej dynastii, której wiecznotrwałość będzie się realizowała przez system następstwa tronu, podkreśla fakt, że po objęciu samodzielnej władzy przez Karakallę i Getę na wybijanych w ich imieniu monetach nie umieszczano deklaracji wiecznej zgody. Ta sama sytuacja dotyczy mennictwa Heliogabala oraz Sewera Aleksandra.

\footnotetext{
${ }^{76}$ Hdn. 3, 9; SHA, Sev. 16, 3-4; SHA, Geta 5, 3; ILS 8916. Chronologia wg: D. Kienast, Römische Kaisertabelle. Grundzüge einer römischen Kaiserchronologie, wyd. 5, Darmstadt 2011, s. 162-166.

${ }^{77}$ SHA, Sev. 16, 3-4. Szerzej na ten temat: K. Królczyk, Der Germanenfeldzug des Kaisers Caracalla im Lichte der epigraphischen Quellen, [w:] S. Ruciński, K. Balbuza, K. Królczyk (red.), Studia Lesco Mrozewicz ab amicis et discipulis dedicata, Poznań 2011, s. 203, wraz z odesłaniem do źródeł i literatury.

${ }^{78}$ Datacja według: D. Kienast, Römische Kaisertabelle, s. 156. Wzmianki źródłowe o adoptio do dynastii Antoninów: Cass. Dio 76, 7, 4; 77, 9, 4; SHA, Sev. 10, 6; SHA, Geta 2, 2. Por. Aur. Vict., Caes. 20, 30.

${ }^{79}$ RIC IV, 1, Sept. Sev. 248 (D).

${ }^{80}$ Cass. Dio 77, 1. Por. Hdn. 3, 10, 1-2; SHA, Sev. 16, 6-7.

${ }^{81}$ Zob. Hdn. 3, 10; 3, 13; Cass. Dio 77, 1, 2; SHA, Sev. 14, 8.
} 


\section{Katarzyna Balbuza \\ CONCORDIA, AETERNITAS IMPERII AND THE DYNASTIC ISSUES IN THE IDEOLOGICAL COINAGE PROGRAMME OF THE FIRST SEVERI}

\section{Summary}

The coinage of the first rulers of the Severan dynasty reflected and disseminated the principal ideas relating to the state which the ruling house sought to propagate. Among the studied coin emissions minted for the first Severi which spread the notion of concord across the state, those which promoted marital concord (concordia felix), perpetual concord (perpetua concordia) and eternal concord (concordia aeterna), were the most interesting and offered the greatest depth of content. At the same time, they constitute the first evidence of this kind in Roman coinage. Analysis of those mintages while taking into account other simultaneous imperial emissions, especially those which propagated the idea of eternal imperial power (aeternitas Imperii), which in itself had never been endorsed in coinage, not only demonstrates the originality of the Severan ideological programme which they publicized by means of coins, but above all, points to ideological relationships between the idea of concord and the idea of eternity, which were symbolically put to use as ideological tools of the ruling dynasty.

\section{Wykaz skrótów}

Gnecchi II - F. Gnecchi, I medaglioni romani descritti ed illustrati da F. Gnecchi, II, Milano 1912.

LGRM - Ausführlicher Lexikon der Griechischen und Römischen Mythologie, Teubner, red. W.H. Roscher, Leipzig 1884-1937.

LIMC - Lexicon Iconographicum Mythologiae Classicae, Teubner, Zürich-Düsseldorf (1981-).

RE - Paulys Realencyclopädie der Klassischen Altertumswissenschaft, red. A. Pauly, G. Wissowa, W. Kroll, K. Witte, K. Mittelhaus, K. Ziegler, J.B. Metzlerscher Verlag, Stuttgart 1894-1980.

RIC IV, 1 - The Roman Imperial Coinage, IV, 1: Pertinax to Geta, red. H. Mattingly, E.A. Sydenham, London 1936.

RIC IV, 2 - The Roman Imperial Coinage, IV, 2: Macrinus to Pupienus, red. H. Mattingly, E.A. Sydenham, C.H.V. Sutherland, London 1938.

RIC VI - The Roman Imperial Coinage, VI: From Diocletian's Reform. A.D. 294 to the Death of Maximinus (A.D. 313), red. C.H.V. Sutherland, R.A.G. Carson, London 1967.

RRC - Crawford M.H., Roman Republican Coinage, Cambridge 1975. 

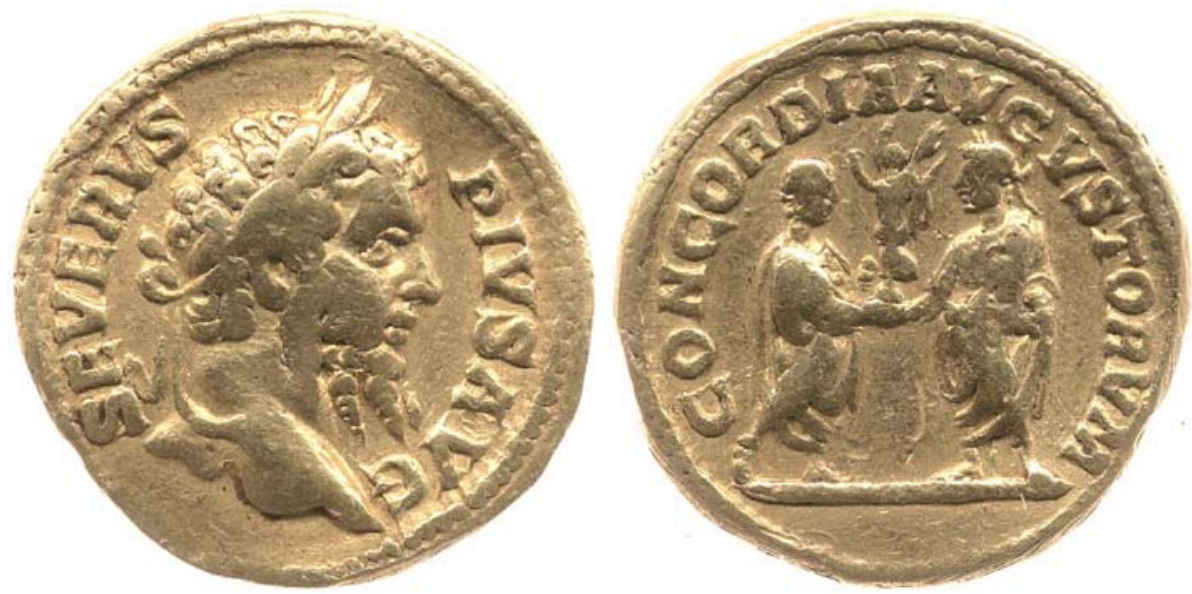

Il. 1. Septymiusz Sewer. Aureus; Rzym, 201-210 r. Aw.: SEVERVS PIVS AVG. Popiersie brodatego Septymiusza Sewera w wieńcu laurowym, w prawo. Rew.: CONCORDIA AVGVSTORVM. Karakalla i Geta ubrani w togi, w wieńcach laurowych, stojący naprzeciwko siebie, trzymający wspólnie posążek Wiktorii na globie. RIC IV, 1, Sept. Sev. 255 @ Trustees of the British Museum
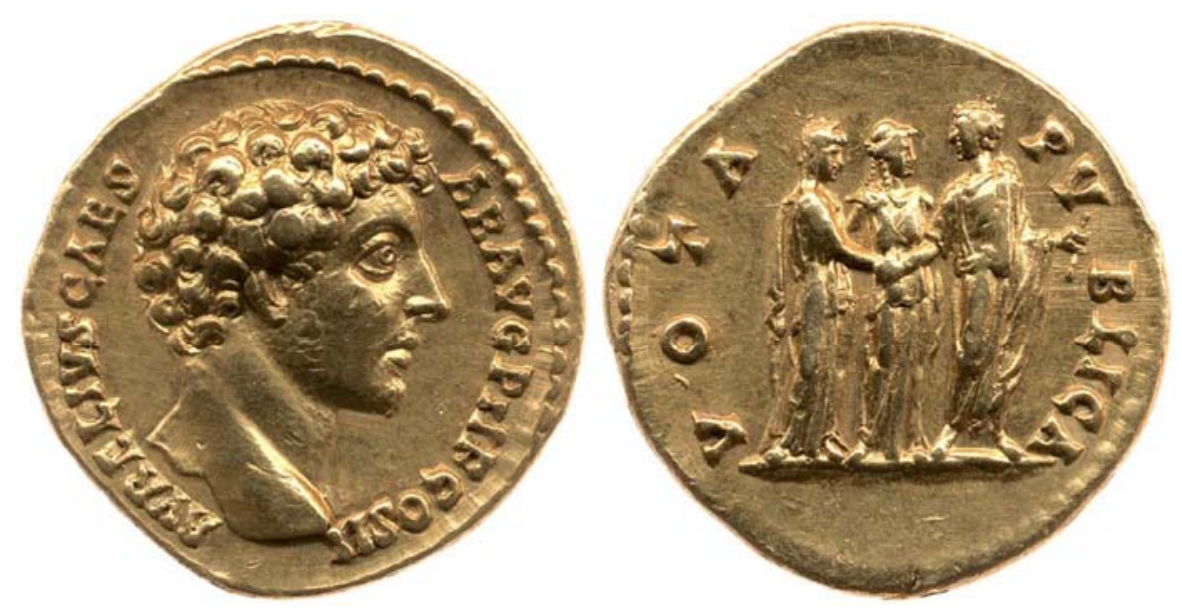

Il. 2. Antoninus Pius. Aureus; Rzym, 145-160 r. Aw.: AVRELIVS CAESAR AVG PII F COS II. Głowa Marka Aureliusza, w prawo. Rew.: VOTA PVBLICA. Para cesarska stojąca naprzeciwko siebie, podająca sobie dłonie. Pomiędzy nimi Konkordia. RIC III, M. Aur. 434 () Trustees of the British Museum 

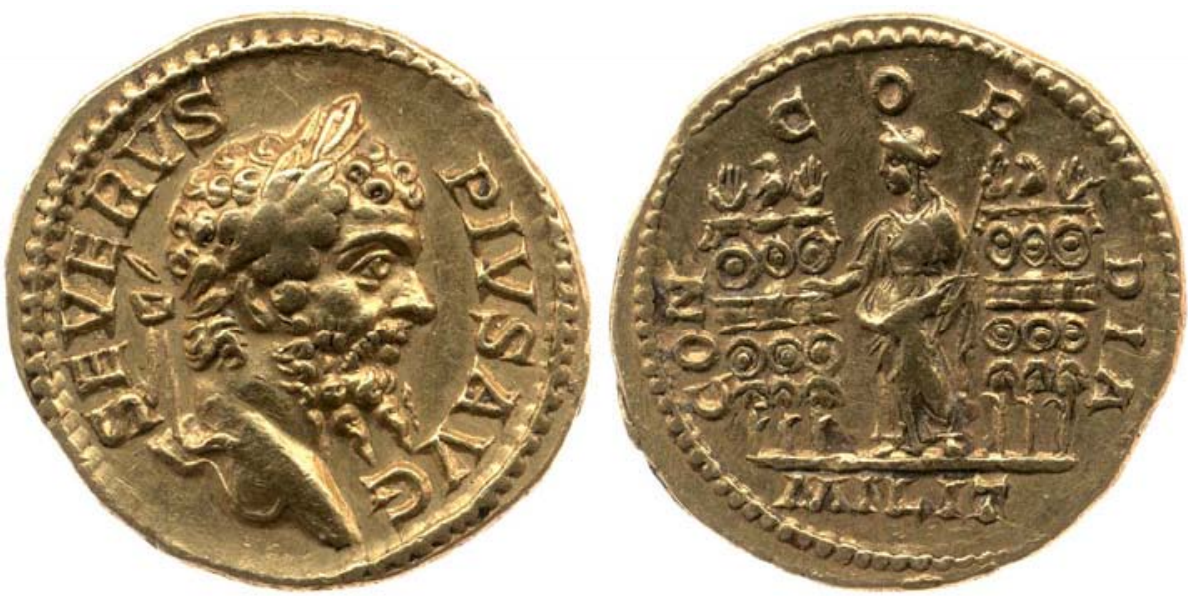

Il. 3. Septymiusz Sewer. Aureus; Rzym, 201-210 r. Aw.: SEVERVS PIVS AVG. Popiersie brodatego Septymiusza Sewera w wieńcu laurowym, w prawo. Rew.: CONCORDIA MILIT. Konkordia stojąca frontalnie, głowa w l., prawą rękę wyciąga w kierunku uchwytu najbliższego sztandaru po lewej stronie. W prawej ręce berło. Po obu stronach Konkordii po trzy sztandary. RIC IV, 1, Sept. Sev. 256 ( ) Trustees of the British Museum
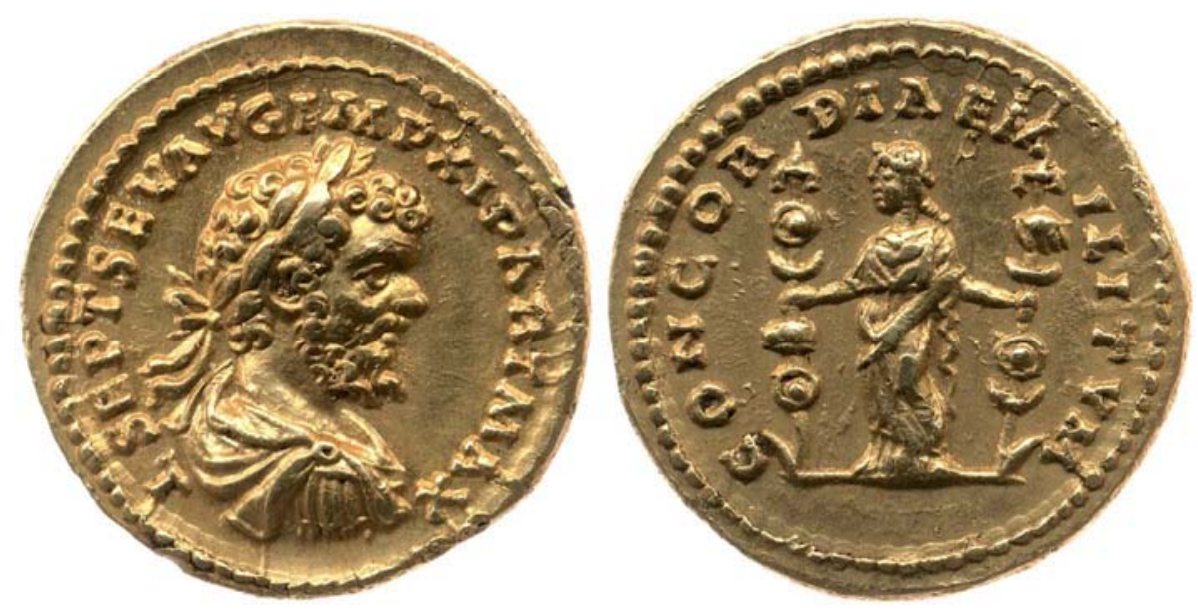

Il. 4. Septymiusz Sewer. Aureus; Laodyceja, 198-202 r. Aw.: L SEPT SEV AVG IMP XI PART MAX. Popiersie brodatego Septymiusza Sewera w wieńcu laurowym, w prawo. Rew.: CONCORDIA MILITVM. Konkordia stojąca frontalnie, głowa w l., pomiędzy dwoma sztandarami. Lewą ręką trzyma sztandar stojący po prawej stronie, prawą ręką - sztandar stojący po lewej stronie. RIC IV, 1, Sept. Sev. 502a @ Trustees of the British Museum 

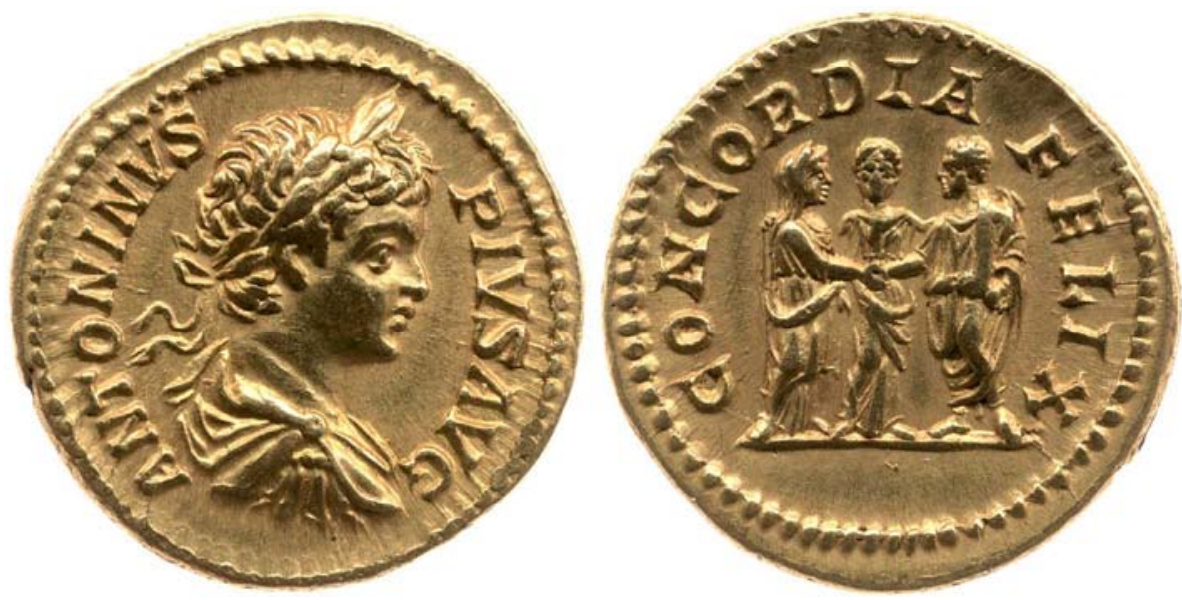

Il. 5. Karakalla. Aureus; Rzym, 201-206 r. Aw.: ANTONINVS PIVS AVG. Popiersie Karakalli $\mathrm{w}$ wieńcu laurowym, w prawo. Rew.: CONCORDIA FELIX. Konkordia stojąca frontalnie pomiędzy Karakallą i Plaucyllą, podającymi sobie ręce. RIC IV, 1, Sept. Sev. 123 @ Trustees of the British Museum
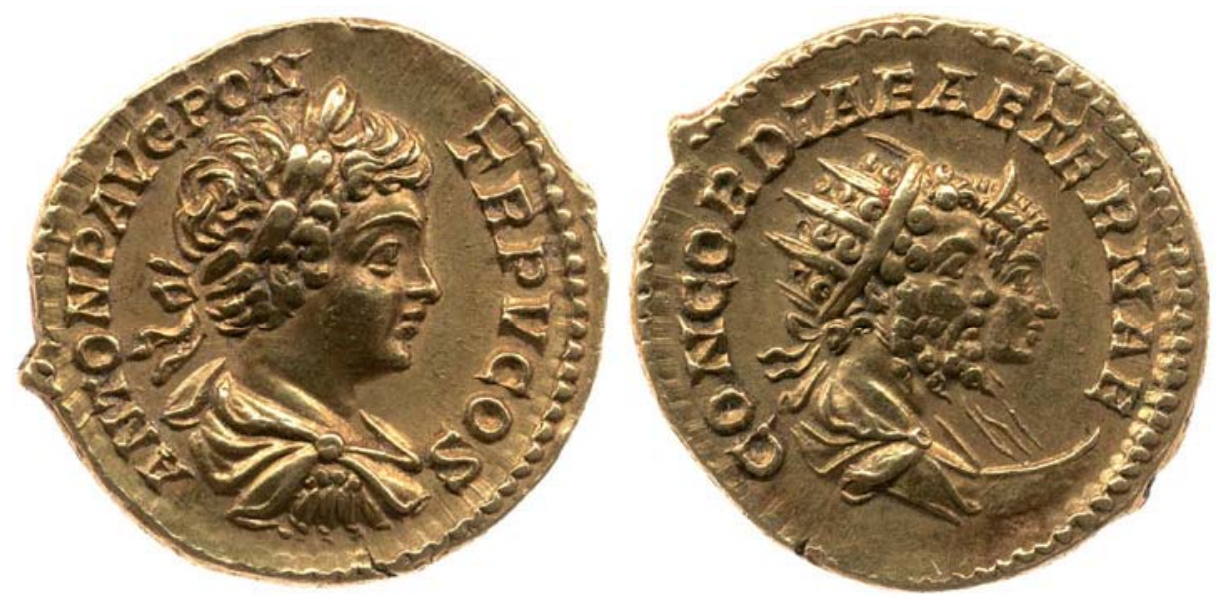

Il. 6. Karakalla. Aureus; Rzym, 202 r. Aw.: ANTON P AVG PON TR P V COS. Popiersie Karakalli $\mathrm{w}$ wieńcu laurowym, w prawo. Rew.: CONCORDIAE AETERNAE. Popiersia Septymiusza Sewera w koronie solarnej i Julii Domny w diademie zwrócone w pr. Podobizna cesarzowej na półksiężycu. RIC IV, 1, Sept. Sev. 59a @ Trustees of the British Museum 

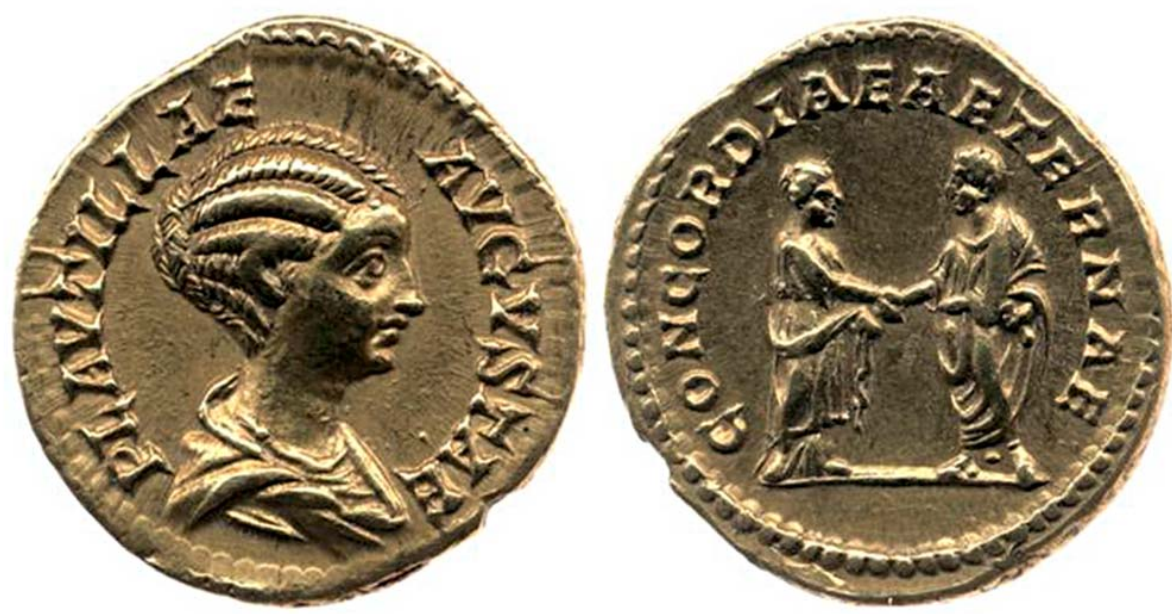

Il.7. Plaucylla. Aureus; Rzym, 202-205 r. Aw.: PLAVTILLAE AVGVSTAE. Popiersie Plaucylli, w prawo. Rew.: CONCORDIAE AETERNAE. Plaucylla i Karakalla stojący naprzeciwko siebie i podający sobie dłonie. RIC IV, 1, Sept. Sev. 361 @ Trustees of the British Museum
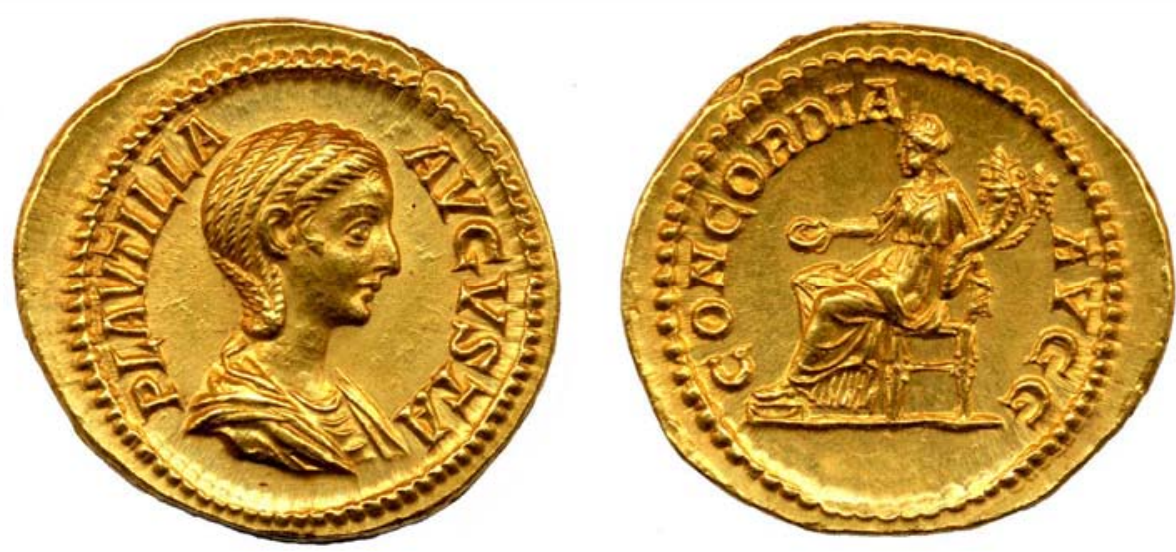

Il. 8. Plaucylla. Aureus; Rzym, 202-205 r. Aw.: PLAVTILLA AVGVSTA. Popiersie Plaucylli, w prawo. Rew.: CONCORDIA AVGG. Konkordia w pozie siedzącej, w lewo, trzymająca czarę ofiarną i podwójny róg obfitości. RIC IV, 1, Sept. Sev. 364 @ Trustees of the British Museum 

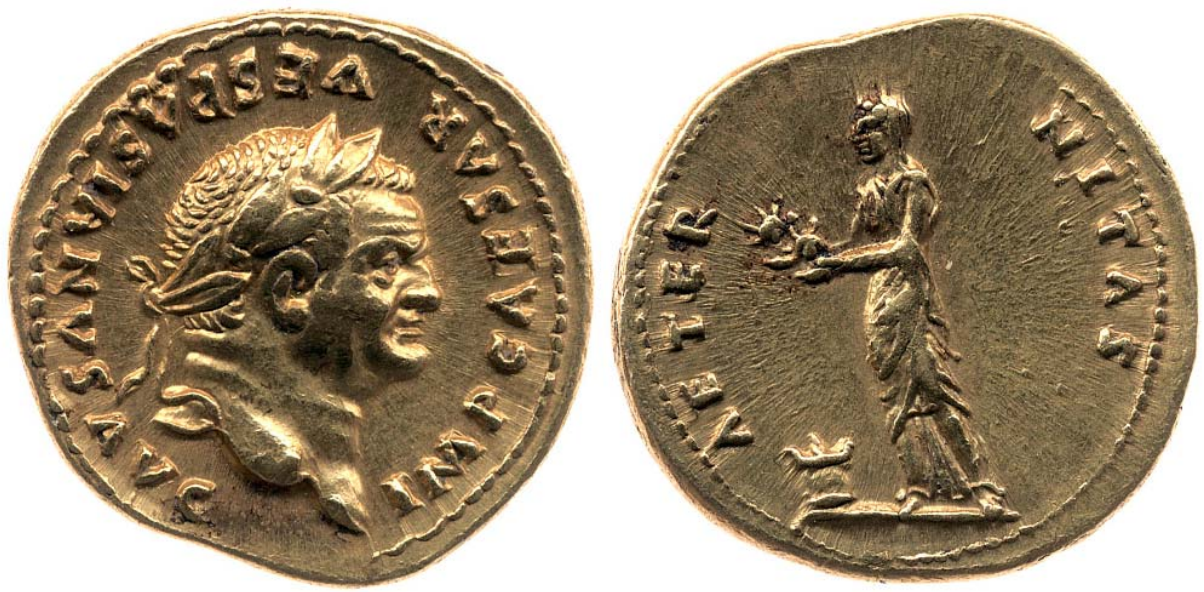

Il. 9. Wespazjan. Aureus; Rzym, 76 r. Aw.: IMP CAESAR VESPASIANVS AVG. Głowa Wespazjana w wieńcu laurowym, w prawo. Rew.: AETERNITAS. Aeternitas odziana w długą szatę, stojąca w l., trzymająca w prawej ręce półksiężyc (lunula), w lewej ręce słońce promieniujące. Przed nią ołtarz. RIC II.1, Vesp. 838 @ Trustees of the British Museum
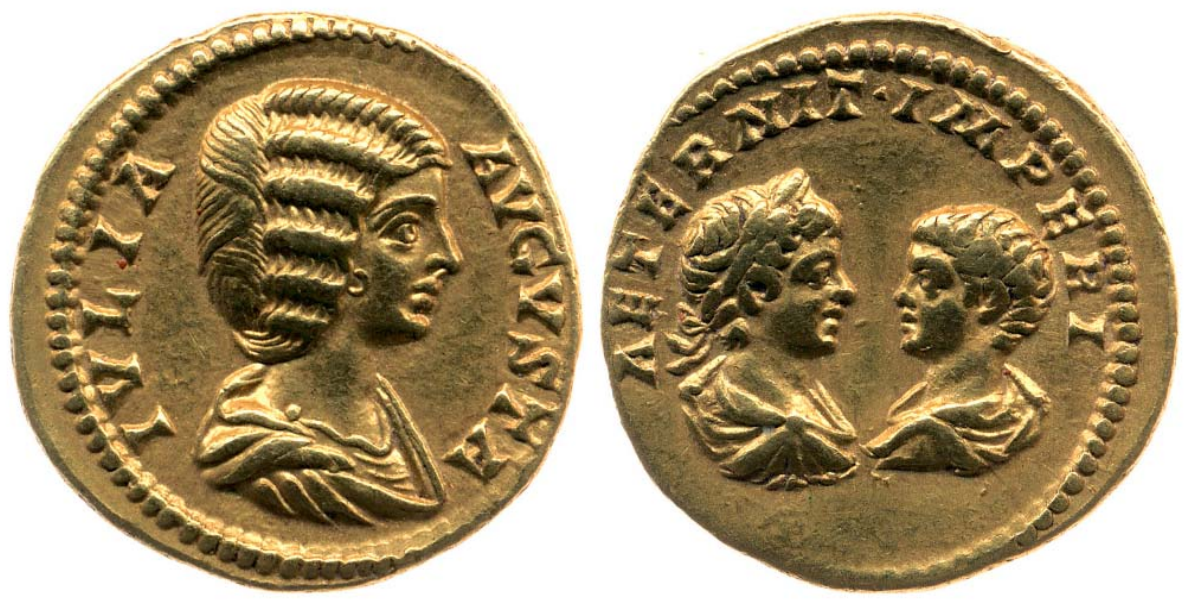

Il. 10. Julia Domna. Aureus; Rzym, 198-209 r. Aw.: IVLIA AVGVSTA. Popiersie Julii Domny, w prawo. Rew.: AETERNIT IMPERI. Zwrócone ku sobie popiersia Karakalli (w wieńcu laurowym, w pr.) i Gety (w l.). RIC IV, 1, Sept. Sev. (Iulia Augusta) 540 @ Trustees of the British Museum 


\section{Bibliografia}

Alexandridis A., Die Frauen des römischen Kaiserhauses von Livia bis Iulia Domna in statuarischer, epigraphischer und numismatischer Überlieferung, Heidelberg 1996.

Alexandridis A., Die Frauen des römischen Kaiserhauses. Eine Untersuchung ihrer bildlichen Darstellung von Livia bis Iulia Domna, Mainz 2004.

Alföldy G., Fasti Hispanienses. Senatorische Reichsbeamte und Offiziere in den spanischen Provinzen des Römischen Reiches von Augustus bis Diokletian, Wiesbaden 1969.

Aust E., Concordia, RE IV, 1901, col. 831-834.

Balbuza K., Aeternitas Augusti. Kształtowanie się i rozwój koncepcji wieczności w (auto)prezentacji cesarza rzymskiego (od Augusta do Sewera Aleksandra), Poznań 2014.

Balbuza K., Personifikacja Aeternitas na monetach rzymskich propagujących ideę wieczności cesarza, StEurGn 8, 2013, s. 7-27.

Balbuza K., Triumfator. Triumf i ideologia zwycięstwa w starożytnym Rzymie epoki cesarstwa, Poznań 2005.

Béranger J., Remarques sur la Concordia dans la propagande monétaire impériale et la nature du principat, [w:] J. Béranger, F. Paschoud, P. Ducrey (red.), Principatus: études de notions et d'histoire politiques dans l'antiquité gréco-romaine, Genève 1973, s. 367-382.

Bergmann M., Die Strahlen der Herrscher. Theomorphes Herrscherbild und politische Symbolik im Hellenismus und in der römischen Kaiserzeit, Mainz 1998.

Berrens S., Sonnenkult und Kaisertum von den Severern bis zu Constantin I (193-337 n. Chr.), Stuttgart 2004.

De Arrizabalaga y Prado L., The Emperor Elagabalus: Fact or Fiction, Cambridge 2010.

Franke P.R., Die Homonoia-Münzen Kleinasiens und der thrakischen Randgebiete, Saarbrücken 1997.

Hersch K.K., The Roman Wedding: Ritual and Meaning in Antiquity, Cambridge 2010.

Hölscher T., Concordia, LIMC V, 1, 1990, s. 479-498; LIMC V, 2, 1990, s. 333-340.

Instinsky H.U., Kaiser und Ewigkeit, Hermes LXXVII 1942, s. 313-355 (=Ideologie und Herrschaft in der Antike, red. H. Kloft, Darmstadt 1979, s. 417-472).

Janiszewska D., Wojna domowa w Rzymie w latach 193-197, Poznań 2010.

Kienast D., Römische Kaisertabelle. Grundzüge einer römischen Kaiserchronologie, wyd. 5, Darmstadt 2011.

Kluczek A., Concordia ordinum, czyli o społecznych funkcjach pieniądza w Cesarstwie Rzymskim, [w:] XIV Ogólnopolska Sesja Numizmatyczna. Upieniężnienie. Kiedy moneta staje się pieniądzem, Nowa Sól 2011, s. 21-42.

Królczyk K., Der Germanenfeldzug des Kaisers Caracalla im Lichte der epigraphischen Quellen, [w:] S. Ruciński, K. Balbuza, K. Królczyk (red.), Studia Lesco Mrozewicz ab amicis et discipulis dedicata, Poznań 2011, s. 203-220.

Królczyk K., Propagatio Imperii. Cesarstwo Rzymskie a świat zewnętrzny w okresie rządów Septymiusza Sewera (193-211 r.), Poznań 2014.

Lobur J.A., Consensus and Concordia and the Formation of Roman Imperial Ideology, New York 2008.

Manders E., Coining Images of Power. Patterns in the Representation of Roman Emperors on Imperial Coinage, A.D. 193-284, Leiden 2012.

Mattingly H., Sydenham E.A. (red.), The Roman Imperial Coinage, IV, 1: Pertinax to Geta, London 1936.

Mennen I., The Image of an Emperor in Trouble. Legitimation and Representation of Power by Caracalla, [w:] L. de Blois, P. Funke, J. Hahn (red.), The Impact of Imperial Rome on Religions, Ritual and Religious Life in the Roman Empire, Proceedings of the Fifth Workshop of the International Network Impact of Empire (Roman Empire, 200 B.C.-A.D. 476), Munster, June 30-July 4, 2004, Leiden-Boston 2006, s. 253-267.

Mikocki T., Zgodna, pobożna, płodna, skromna, piękna... Propaganda cnót żeńskich w sztuce rzymskiej, Wrocław 1997. 
Morawiecki L., Pax et Concordia - polityczne i religijne aspekty personifikacji w republikańskim Rzymie, [w:] R. Sajkowski (red.), Religia i polityka w świecie antycznym, Ostróda 2005, s. 132-156.

Noreña C., Hadrian's Chastity, Phoenix 61, 2007, s. 296-317.

Noreña C., Imperial Ideals in the Roman West: Representation, Circulation, Power, Cambridge 2011.

Pera R., Homonoia sulle monete da Augusto agli Antonini, Genova 1984.

Peter R., Concordia, LGRM I, 1884-1890, s. 914-922.

Rowan C., Divine Ideology and the Visualisation of Imperial Power in the Severan Period, Cambridge 2012.

Salz C., Die Mondsichel der Kaiserin, [w:] L. De Blois, P. Funke, J. Hahn (red.), The Impact of Imperial Rome on Religions, Ritual and Religious Life in the Roman Empire. Proceedings of the Fifth Workshop of the International Network Impact of Empire (Roman Empire, 200 B.C.-A.D. 476), Münster, June 30-July 4, 2004, Leiden-Bristol 2006, s. 232-237.

Shapiro H.A., Homonoia, LIMC V, 1, 1990, s. 476-479.

Vacano O., Typenkatalog der antiken Münzen Kleinasiens, red. D. Kienast, Berlin 1986.

Varner E.R., From Caligula to Constantine: Tyranny and Transformation in Roman Portraiture, Atlanta 2000.

Varner E.R., Mutilation and Transformation. Damnatio Memoriae and Roman Imperial Portraiture, Leiden 2004.

Walsh P.G., Livy: His Historical Aims and Metods, Oxford 1961.

Zanzarri P., La concordia romana: politica e ideologia nella monetazione dalla tarda repubblica ai Severi, Rome 1997. 
